\title{
Pengalaman Self Disclosure Wanita yang Menikah Muda Dalam Membangun Komitmen Selama Menjalankan Proses Ta'aruf
}

\author{
Nabila Noerfadjria, Yulianti Yulianti \\ Bandung, Indonesia. \\ *noerfadjria@gmail.com yulianti@unisba.ac.id
}

Prodi Manajemen Komunikasi, Fakultas Ilmu Komunikasi, Universitas Islam

\begin{abstract}
Marriage is a commitment in believing that a relationship is a lifelong relationship, and believing that the chosen partner is the right choice. In Islam, before a pair of individuals establishes themselves to do marriage, there are stages known as Ta'aruf. The time period is quite short, the interaction is limited and there is no space and time to be alone between the two parties before the marriage contract is signed, and can lead to a lack of openness between the prospective husband or wife. The less the adjustment process, the less likely it is to build commitment. Therefore, the research wants to explain how each individual interacts with each other and opens themself so that they can build commitment to marry at a young age through the Ta'aruf process. The purpose of this research is to find out their experiences of Self Disclosure during the Ta'aruf process. The two main focuses are viewed from the experience of the subject as an "actor" seen from the concept of "becoming a process" so that the researcher is able to know why the subject chose the Ta'aruf path, and the inside story experienced. The research method used is phenomenology by conducting In-Depth Interview and Literature Study. The results of this study indicate that the self-disclosure that occurs when ta'aruf does not reach the exlorative stage and during the process the information provided is limited to information covering household life.
\end{abstract}

Keywords - Self Disclosure, Ta'aruf, Young Marriage

\begin{abstract}
Abstrak. Pernikahan merupakan komitmen dalam meyakini bahwa hubungan yang dijalani merupakan hubungan seumur hidup dan pasangan yang dipilih merupakan pilihan yang tepat. Dalam Islam sendiri sebelum sepasang individu memantapkan diri untuk melakukan pernikahan, ada tahapan yang disebut dengan istilah Ta'aruf. Jangka waktunya yang cukup singkat, terbatasnya interaksi untuk saling mengenal satu sama lain, dan tidak ada ruang dan waktu untuk bisa berduaan antara kedua belah pihak sebelum ada akad pernikahan, dapat menyebabkan kurangnya keterbukaan antara pasangan calon suami atau istri. Maka dari itu, peneliti ingin menjelaskan bagaimana masing-masing individu saling berinteraksi dan membuka diri untuk kemudian dapat memantapkan hati dan membangun komitmen menikah di usia muda melalui proses Ta'aruf. Tujuan penelitian ini untuk mengetahui pengalaman Self Disclosure mereka selama menjalankan proses Ta'aruf. Dua fokus utama tersebut ditinjau dari pengalaman subjek sebagai "aktor" yang dilihat dari konsep "proses menjadi" sehingga peneliti mampu mengetahui mengapa subjek memilih jalan Ta'aruf, dan inside story yang dialami. Adapun metode penelitian yang digunakan adalah fenomenologi dengan melakukan In-Depth Interview. Hasil dari penelitian ini menunjukan bahwa pengungkapan diri yang terjadi pada saat ta'aruf tidak mencapai tahap eksloratif dan selama prosesnya informasi yang diberikan hanya sebatas informasi yang mencakup seputar kehidupan berumah tangga.
\end{abstract}

Kata Kunci- Self Disclosure, Ta'aruf, Nikah Muda 


\section{A. Pendahuluan}

Komitmen adalah hal dasar yang harus dimiliki seseorang saat ingin menjalin suatu hubungan, terutama jika tujuannya untuk membangun rumah tangga. Komitmen sangat diperlukan untuk mencapai keharmonisan dalam suatu hubungan. Tanpa adanya sebuah komitmen, maka kemungkinan terjadinya pertengkaran akibat perbedaan pemikiran dan sudut pandang akan semakin besar. Dalam komitmen, terdapat dua individu yang saling mengikat janji dan itu tertuang dalam bentuk tindakan menuju ke arah yang telah disepakati oleh kedua belah pihak.

Komitmen merupakan proses meyakini bahwa hubungan yang dijalani merupakan hubungan untuk seumur hidup, berarti meyakini bahwa pasangan yang dipilih merupakan pilihan yang tepat. Keyakinan dan Kepercayaan merupakan suatu sikap yang ditunjukkan oleh suatu individu saat ia merasa cukup tahu dan menyimpulkan bahwa dirinya telah mencapai asumsi yang benar dan nyata.

17 dari 20 puluh orang ta'aruf yang diteliti mengenai penyesuaian pernikahannya teridentifikasi memiliki penyesuaian pernikahan yang buruk, hal ini berbanding terbalik dengan pasangan yang menikah melalui pacaran dimana penyesuaian pernikahan yang buruk hanya terdapat pada 2 orang (Nawangsih et al., 2010). Ta'aruf merupakan tahap perkenalan antara satu orang dengan orang lain yang bertujuan untuk saling memahami.

Dalam pernikahan, proses ta'aruf antara pria dan wanita yang ingin menikah berarti saling mengenal sebelum menikah. Ta'aruf menjadi mulia karena niatnya yang suci. Ta'aruf juga memelihara hubungan ketuhanan yang lebih tinggi dengan menjaga kehormatan diri dan pasangan. Melalui ta'aruf, masing-masing individu dapat lebih menjaga kehormatan diri agar terhindar dari perbuatan zina karena adanya perantara yang mendampingi interaksi mereka.

Proses ta'aruf ini biasanya berlangsung dalam jangka waktu 2-4 bulan saja. Hal ini dikarenakan jika memperlama proses ta'aruf ditakutkan menjadi celah setan untuk menggoda manusia. Apabila pertahanan iman kurang, maka masing-masing pihak akan tergoda untuk menghabiskan waktu bersama, bersentuhan, hingga bermesraan sebelum adanya ikatan yang sah. Maka dari itu dianjurkan untuk tidak memperlama ta 'aruf, apalagi disengaja tanpa alasan dan tahapan yang jelas.

Dimana hal ini pun menjadi salah satu kekurangan dari ta'aruf. Para calon pasangan ta'aruf cenderung kurang mengenal dan juga tidak terlalu erat memahami sisi emosional, psikologis maupun biologis calon pasangannya dikarenakan mereka hanya bisa saling mengenal melalui interpretasi dan persepsi dari pihak ketiga yang masih kurang begitu jelas (abu-abu).

Pernikahan membutuhkan kematangan yang bukan hanya bersifat biologis, melainkan juga kematangan psikologis. Perbedaan yang cukup signifikan terlihat dalam kematangan emosi pria dan wanita yang menikah muda, dimana pria mempunyai tingkat kematangan emosi yang lebih tinggi ketimbang wanita, pria lebih rasional dan menggunakan logika sedangkan wanita lebih emosional dan penuh perasaan (Khairani \& Putri, 2008).

Menurut Santrock, umumnya masyarakat percaya bahwa wanita memiliki kematangan emosional yang lebih ketimbang laki-laki (Khairani \& Putri : 2008). Berdasarkan data demografis, kematangan emosi tertinggi pada wanita dimiliki pada usia 24 tahun (Khairani \& Putri, 2008). Menurut Blood, kematangan emosi, sosial, peran, usia, dan finansial merupakan faktor penting dalam menentukan kesiapan menikah (dalam Sari \& Sunarti, 2013). Kematangan seseorang ini dapat dilihat dari rentang umurnya. Menurut Departemen Kesehatan RI (dalam Santika, 2015), usia manusia terbagi ke dalam 9 massa : 
Tabel 1. Kategori Umur

\begin{tabular}{cll}
\hline No. & \multicolumn{1}{c}{ Kategori Umur } & \multicolumn{1}{c}{ Umur/Usia } \\
\hline 1. & Massa Balita & $0-5$ tahun \\
2. & Massa Kanak - Kanak & $5-11$ tahun \\
3. & Massa Remaja Awal & $12-16$ tahun \\
4. & Massa Remaja Akhir & $17-25$ tahun \\
5. & Massa Dewasa Awal & $26-35$ tahun \\
6. & Massa Dewasa Akhir & $36-45$ tahun \\
7. & Massa Lansia Awal & $46-55$ tahun \\
8. & Massa Lansia Akhir & $56-65$ tahun \\
9. & Masa Manula & $65-$ sampai ke atas \\
\hline
\end{tabular}

Masa dewasa merupakan usia yang paling ideal dalam hal kesiapan menikah, kondisi psikis dan fisik yang sudah stabil mampu menopang kehidupan keluarga baik secara psikis, emosional, ekonomi maupun sosial. Usia ideal untuk menikah dan kedewasaan jiwa manusia sangat berpengaruh dalam kehidupan rumah tangga.

Menurut Walgito, seseorang dikatakan siap menikah jika mereka bisa membuat keputusan sendiri dan sudah dewasa dalam berfikir serta bertindak (dalam Khairani \& Putri, 2008). Jadi kedewasaan adalah salah satu Faktor yang menentukan sukses tidaknya sebuah keluarga. Belakangan ini, kita sering mendapati fenomena perceraian yang tampak hampir di semua kalangan. Bukan hanya kalangan artis saja namun sampai pada kalangan pemuka agama.

Angka perceraian di Jawa Barat berdasarkan data dari Pengadilan Tinggi Agama (PTA) Jabar dalam situsnya http://kabayan.pta-bandung.go.id/pengawasan sipp/\#, pada Tahun 2020 terdapat total 76.392 kasus gugat cerai, dimana pemohon atau penggugat dengan rentang umur 21-30 Tahun menduduki peringkat kedua.

Tabel 2.Statistik Berdasarkan Umur Pemohon/Penggugat

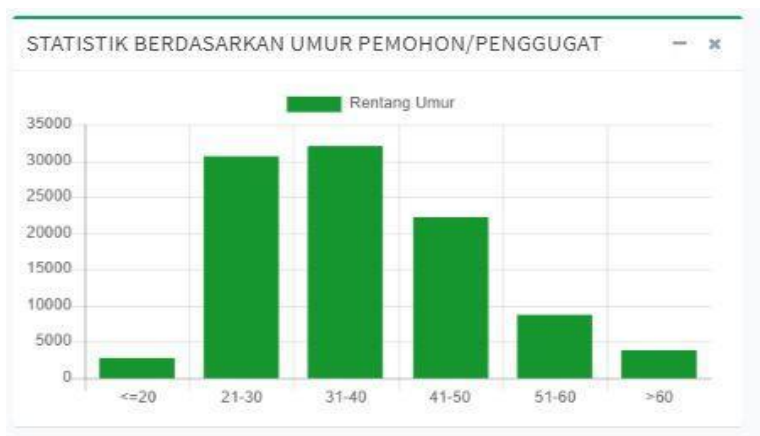

Usia pernikahan yang terlalu muda dapat mengakibatkan meningkatnya kasus perceraian karena kurangnya kesadaran untuk bertanggung jawab dalam kehidupan berumah tangga bagi suami maupun istri. Masih banyak pasangan menikah muda yang belum menyadari dan belum dapat bertoleransi dengan hak dan tanggung jawabnya masing-masing. Dilihat dari aspek kepuasan pernikahan, sebagian perempuan yang menikah melalui ta'aruf memiliki kepuasan pernikahan yang rendah diakibatkan dari cara berfikir pasangan yang terlalu menyepelekan masalah, dingin dan kurang peka sehingga menimbulkan konflik berupa emosi baik verbal maupun non-verbal (Borualogo \& Rahmatinna, 2011).

Maka dari itu, peneliti ingin mengetahui bagaimana masing-masing individu saling membuka diri untuk kemudian dapat memantapkan hati dan membangun komitmen menikah di usia muda melalui proses ta'aruf. Karena jika proses penyesuaian tidak berjalan dengan baik maka akan timbul konflik yang jika tidak dikomunikasikan dengan baik akan berujung pada perceraian.

Berdasarkan latar belakang yang telah diuraikan, maka tujuan dalam penelitian ini diuraikan dalam pokok-pokok sebagai berikut.

1. Untuk mengetahui pengalaman Self Disclosure wanita usia muda selama menjalankan proses Ta'aruf 


\section{B. Metodologi Penelitian}

Metode penelitian yang digunakan dalam penelitian ini adalah metode kualitatif dengan menggunakan pendekatan fenomenologi untuk melihat dan mengetahui bagaimana Self Disclosure wanita yang menikah muda dalam melakukan proses ta'aruf. Subjek penelitian yang digunakan dalam penelitian ini yaitu tiga wanita di pengajian ICG Wanayasa, Purwakarta yang menikah muda melalui Ta'aruf dibawah umur 21 tahun.

Peneliti melakukan teknik pengumpulan data dengan menggunakan In-Depth Interview dan Studi Literatur. Uji keabsahan data dalam penelitian ini hanya melalui Triangulasi sumber dan Membercheck. Sedangkan untuk Proses analisis datanya dilakukan secara fenomenologis dengan mengikuti saran berdasarkan Fenomenologi Husserl yang terdiri dari empat tahap yaitu:

1. Tahap Transkripsi

2. Tahap Pengklasifikasian Pernyataan -Pernyataan Penting

3. Tahap Pengklasifikasian Unit-Unit Makna

4. Tahap Deskripsi Esensi

Teori Penetrasi sosial dikembangkan untuk menjelaskan bagaimana pertukaran informasi dan fungsi dalam pengembangan dan pemutusan hubungan interpersonal. Teori ini dipopulerkan oleh Irwin Altman \& Dalmas Taylor (1973) menurut mereka, sebelum memahami penetrasi sosial, kita harus terlebih dahulu memahami kompleksitas manusia. Penetrasi sosial secara khusus tercapai melalui pengungkapan diri, yaitu proses yang bertujuan untuk mengungkapkan informasi tentang diri dimana secara umum membahas tentang bagaimana proses komunikasi interpersonal.

Altman dan Taylor (dalam Prambudi, 2016) membahas tentang bagaimana perkembangan kedekatan dalam suatu hubungan. Menurut mereka, pada dasarnya kita akan mampu untuk berdekatan dengan seseorang yang lain sejauh kita mampu melalui proses. Teori penetrasi sosial mengibaratkan manusia seperti bawang. Jika kita mengupas kulit bawang, kita akan menemukan lapisan kulit yang lain. Hal yang sama berlaku pada kepribadian manusia. Dimana pada dasarnya manusia itu memiliki beberapa layer kepribadian, melalui interaksi yang terjalin, mereka saling mengelupasi lapisan informasi mengenai satu sama lain.

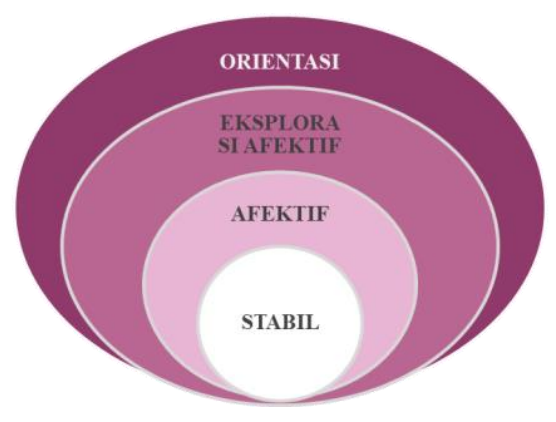

Gambar 1. Teori penetrasi sosial

Teori penetrasi sosial mengibaratkan manusia seperti bawang. Jika kita mengupas kulit bawang, kita akan menemukan lapisan kulit yang lain. Hal yang sama berlaku pada kepribadian manusia. Dimana pada dasarnya manusia itu memiliki beberapa layer kepribadian, melalui interaksi yang terjalin, mereka saling mengelupasi lapisan informasi mengenai satu sama lain. Berikut beberapa tahapan dalam penetrasi sosial menurut Altman dan Taylor :

1. Orientasi

Tahapan awal dalam interaksi dimana hanya sedikit dari kita yang terbuka untuk orang lain.

2. Pertukaran penjajakan afektif

Dalam tahap ini, mulai terjadi pembukaan area personal dan interaksi yang lebih 
mengarah ke aspek pribadi lawan bicara.

3. Pertukaran afektif

Pada tahap ini mulai terbentuk adanya hubungan yang dekat dan intim. Interaksi yang terjalin lebih intim dan terkesan "tanpa beban".

4. Pertukaran stabil

Tahap terakhir yaitu tahapan dimana pengungkapan pikiran, perasaan, dan perilaku, mengarah pada munculnya spontanitas dan keunikan hubungan yang lebih intim dan personal.

Dalam perspektif teori penetrasi sosial, Altman dan Taylor (dalam Rorong, 2018) menjelaskan beberapa uraian sebagai berikut : Lebih mudah bagi seseorang untuk membicarakan hal-hal yang tidak penting bagi orang lain daripada membicarakan hal-hal yang lebih pribadi atau personal, Tingkat penetrasi pada awalnya akan sangat cepat tetapi semakin dalam informasi yang diberikan, tingkat penetrasi akan semakin menurun dan Depenetrasi merupakan proses penetrasi yang secara bertahap menghilang.

Menurut teori penetrasi sosial, penentuan kedekatan hubungan ditentukan oleh prinsip cost-benefit (analisis untung-rugi). Setelah mengenal seseorang, pada dasarnya kita akan menghitung cost and loss factor atau indeks kepuasan hubungan dalam hubungan dengan orang tersebut. Jika hubungan tersebut saling menguntungkan, kemungkinan besar akan terus berlanjut, dan proses penetrasi sosial juga akan terus berlanjut.

Self disclosure atau pengungkapan diri diartikan oleh DeVito sebagai salah satu bentuk dari komunikasi interpersonal yang dimana setiap individu membuka dirinya melalui pertukaran informasi mengenai diri sendiri. Informasi yang diberikan biasanya bersifat personal atau yang biasa dirahasiakan oleh masing-masing indidivu seperti : Kepercayaan, Nilai-Nilai, Keinginan, Kebiasaan, Kualitas Diri atau Karakteristik. Pengungkapan diri yang dilakukan secara tepat merupakan indikasi dari kesehatan mental seseorang.

Morton (dalam Defrian, 2015) menjelaskan bahwa pengungkapan diri adalah kegiatan berbagi perasaan dan informasi akrab dengan orang lain. Pengungkapan diri dapat menjadi penilaian descriptive maupun evaluative. Descriptive self dislocusre, seseorang mendeskripsikan berbagai fakta tentang dirinya yang mungkin tidak diketahui oleh audiens, seperti pekerjaan, tempat tinggal, dll. Evaluative self disclosure, yaitu orang yang mengungkapkan pendapat atau perasaan pribadinya, misalnya menyukai perasaan orang tertentu, merasa cemas karena terlalu gemuk, tidak suka bangun pagi, dsb.

Pengungkapan diri menurut Jourard (dalam Natalia, 2012:12) memiliki tiga aspek, yaitu:

\section{Aspek Keluasan}

Ini mengacu pada cakupan materi yang diungkapkan dan dijelaskan dalam enam kategori informasi tentang diri sendiri, yaitu sikap dan pendapat, perasaan dan minat, pekerjaan atau studi, uang, kepribadian dan tubuh.

2. Aspek Kedalaman

Mengacu pada empat tingkatan keterbukaan diri, yaitu tidak pernah mengungkapkan aspek diri tertentu kepada orang lain, berbicara secara general, bercerita secara komprehensif dan rinci, berbohong atau mendistorsi aspek tertentu dari diri sendiri, sehingga memberikan citra diri yang salah pada orang lain.

3. Target atau sasaran

Objek pengungkapan diri terdiri dari lima orang yaitu ibu, ayah, teman laki-laki, teman perempuan dan pasangan..

Papu (Dalam Hamdan, 2009: 14) menjelaskan beberapa manfaat keterbukaan diri yaitu sebagai sarana meningkatkan kesadaran diri, membangun hubungan lebih dekat dan lebih dalam, saling membantu dan lebih bermakna bagi kedua belah pihak, mengembangkan keterampilan komunikasi, mengurangi stigma dan meningkatkan penerimaan diri, serta menyelesaikan berbagai masalah dalam hubungan interpersonal, dan membebaskan diri dari beban pikiran yang menimbulkan ketegangan dan tekanan.

Ta'aruf berasal dari bahasa Arab yaitu "ta'arofu" yang memiliki pengertian : saling mengenal. Ta'aruf merupakan tahap perkenalan antara satu orang dengan orang lain, yang bertujuan untuk saling memahami. Dalam pernikahan, proses Ta'aruf antara pria dan wanita 
yang ingin menikah berarti saling mengenal sebelum menikah. Ta'aruf menjadi mulia karena niatnya suci. Ta'aruf juga memelihara hubungan ketuhanan yang lebih tinggi dengan menjaga kehormatan diri dan pasangan.

Dalam proses nya, Ta'aruf melibatkan pihak ketiga yang menjadi pembimbing selama jalannya proses ta'aruf, atau bisa juga menggunakan lembaga yang dapat dipercaya sebagai perantara atau perantara dari keluarga untuk memilih sesuai kriteria yang diinginkan. Ta'aruf merupakan proses awal untuk memasuki tahap pernikahan yang memikul tanggung jawab penuh dalam batas waktu yang telah disepakati. Orang yang berani ta'aruf berarti mereka lebih rela menikah secara psikologis, karena niat awal mereka adalah menikah. Bergaul dengan lawan jenis dapat mengotori hati meski tidak perlu menikah. Ini berbeda dari ta'aruf untuk waktu yang singkat.

Tidak ada pedoman khusus tentang tata cara ta'aruf dalam Islam, tetapi harus sesuai dengan norma antara lawan jenis dan hukum Islam. Sebagian orang meyakini bahwa proses Ta'aruf terbagi menjadi dua proses, yaitu pertama pertukaran data biografi, kemudian pertemuan yang didampingi oleh seorang murabbi. Beberapa orang ada juga yang bertanya apakah keluarga bersedia memperkenalkan mereka kepada kandidat Ta'aruf melalui orang tua, saudara atau topik, dan kemudian memutuskan apakah mereka bersedia untuk bertemu.

\section{Pembahasan dan Diskusi}

\section{Pernyataan-Pernyataan Mengenai Pengalaman Self Disclosure}

Tabel 3. Pernyataan-Pernyataan Mengenai Pengalaman Self Disclosure

\begin{tabular}{|c|c|c|c|}
\hline $\mathbf{N}$ & Pernyataan & & \\
\hline 1 & $\begin{array}{c}\text { cuma dikenalin abis } \\
\text { itu perkenalan } \\
\text { satu sama lain }\end{array}$ & 1 & $\begin{array}{l}\text { ngga ada perasaan segan untuk membuka diri karena calonku bisa } \\
\text { menyetarakan aku }\end{array}$ \\
\hline 2 & $\begin{array}{l}\text { gapake cv atau } \\
\text { apapun }\end{array}$ & 1 & kita tukeran CV untuk tahu satu sama lain \\
\hline 3 & $\begin{array}{l}\text { ada } \begin{array}{l}\text { kontak langsung } \\
\text { berdua, kaya } \\
\text { ketemu, } \\
\text { ngobrol }\end{array} \\
\end{array}$ & 1 & aku insyaallah nerima pasangan aku \\
\hline 4 & $\begin{array}{l}\text { nadzar (melihat) aku, } \\
\text { karena aku pake } \\
\text { cadar }\end{array}$ & 1 & belum terlalu ngerasa klop pada saat tukeran $\mathrm{cv}$ \\
\hline 5 & $\begin{array}{r}\text { aku yakin insyaallah } \\
\text { dia ga bakal } \\
\text { ngasih tau orang }\end{array}$ & 1 & dapet infomasi mengenai suami dari keponakannya \\
\hline & $\begin{array}{l}\text { lain tentang } \\
\text { wajah aku tuh } \\
\text { gimana kalo dia } \\
\text { emang paham } \\
\text { agama }\end{array}$ & & \\
\hline 6 & $\begin{array}{cr}\text { dari tetehnya } & \text { suami } \\
\text { juga } & \text { cerita, } \\
\text { adiknya } & \text { tuh } \\
\text { punya } & \text { sikap } \\
\text { kaya gimana }\end{array}$ & 1 & gaada kontak langsung sama sekali selama proses ta'aruf berjalan \\
\hline 7 & $\begin{array}{l}\text { lebih banyak } \\
\text { pengenalan } \\
\text { lewat ngobrol } \\
\text { dengan perantara }\end{array}$ & 1 & keluarganya itu jadi wasilah (perantara) aku sama suami buat ta'aruf \\
\hline 8 & $\begin{array}{cr}\text { suami } & \text { banyak } \\
\text { ngobrol } & \text { sama } \\
\text { ayah ku lewat } \\
\text { telfon }\end{array}$ & 1 & bertemu sama orang tua nya suami \\
\hline 9 & ayah juga ngasih tau & 1 & kami komunkasi lewat perantara dan orang terdekat \\
\hline
\end{tabular}


tentang sifat dan

karakter aku

gimana

10 kami juga banyak saling bertanya

dan bertukar

informasi

Kata Kunci : Dikenalin, Cocok, Ketemu, Intens, Pihak ketiga, CV, Nadzar, Fisik, Cerita, Kehidupan, Sikap, Perantara, Ngobrol, Telfon, Visi misi, Background Keluarga, Sifat, Karakter, Informasi, Orang terdekat

Keterangan: Item-item pernyataan yang dicetak miring merupakan pernyatan deskripsi struktural, sedangkan yang dicetak normal adalah pernyataan deskripsi tekstural.

\begin{tabular}{|c|c|}
\hline No & Makna \\
\hline 1 & Ta'aruf dapat berlangsung tanpa atau dengan bertukar cv \\
\hline 2 & $\begin{array}{l}\text { Nadzar merupakan tahapan dalam ta'aruf bagi wanita yang memakai cadar untuk memperlihatkan } \\
\text { wajahnya }\end{array}$ \\
\hline 3 & $\begin{array}{l}\text { Informasi yang didapat atau diberikan selama ta'aruf disampaikan melalui orang terdekat seperti } \\
\text { anggota keluarga atau teman dekat calon pasangan }\end{array}$ \\
\hline 4 & Proses ta'aruf dapat berlangsung tanpa atau melalui pertemuan kedua belah pihak \\
\hline 5 & Pihak ketiga selalu ada untuk menjadi pendamping selama proses ta'aruf berlangsung \\
\hline 6 & Tidak ada kontak secara langsung diantara wanita dan pasangannya yang sedang menjalankan ta'aruf \\
\hline 7 & Selama menjalankan ta'aruf wanita tidak merasa segan untuk membuka informasi mengenai dirinya \\
\hline 8 & Proses saling memberi informasi ini tidak menggambarkan sepenuhnya karakter dan diri mereka \\
\hline
\end{tabular}

A. Makna yang Terbentuk dari Pernyataan-Pernyataan Mengenai Pengalaman Self Disclosure

Pengalaman Self Disclosure Wanita yang Menikah Muda Selama Menjalankan Proses Ta'aruf

Menurut Devito, banyak faktor yang mepengaruhi apakah seorang individu akan mengungkapkan dirinya atau tidak. Perbedaan budaya, kepribadian, siapa yang mendengar dan topik yang dibahas menjadi faktor penentu apakah seseorang akan terbuka atau tertutup mengenai dirinya. Namun hal tersebut tidak berlaku dalam proses Ta'aruf yang dijalankan oleh ketiga informan ini dikarenakan ketiga informan menjalani Ta'aruf tanpa adanya paksaan dan berdasarkan kesadaran mereka sendiri. Maka dari itu tidak ada rasa segan sedikit pun untuk mereka membuka diri selama proses Ta'aruf.

Teori penetrasi sosial akan digunakan untuk memahami fenomena pengalaman Self Disclosure ketiga informan ini. Menurut Morissan (dalam Ridwansyah : 2018) teori ini mengetahui atau mengenal diri orang lain dengan cara "masuk ke dalam" (penetrating) orang yang bersangkutan. Dimana orang tersebut memiliki dua macam aspek yaitu aspek keluasan yang berisikan berbagai jenis informasi mengenai dirinya dan aspek kedalaman yang berisikan informasi detail dan mendalam mengenai satu atau dua aspek dari diri orang lain tersebut. Altman dan Taylor (dalam Kadarsih : 2009) menyatakan bahwa penetrasi sosial terbagi kedalam beberapa proses yaitu proses pertukaran informasi, keluasan dan kedalaman hubungan, serta kepuasan hubungan.

1. Pertukaran Informasi

Karakteristik penting dalam komunikasi menurut Ronald dan George (B. Adler \& Rodman : 2006) adalah adanya pertukaran informasi antara individu-individu melalui sebuah sistem perlambang, tanda, atau perilaku yang sama baik berupa ekspresi dan pertukaran berbagai fakta, pendapat, gagasan atau perasaan. Dalam komunikasi interpersonal diperlukan paling sedikit dua orang agar proses komunikasi berjalan. Salah satu pihak dalam konteks komunikasi interpersonal berperan sebagai pengirim pesan dan pihak lain berperan sebagai penerima pesan. 
Pertukaran informasi yang dilakukan oleh $\mathrm{N}$ dan $\mathrm{F}$ tidak langsung disampaikan kepada target person (calon pasangan), melainkan melalui anggota keluarga nya yaitu figure ayah yang berperan sebagai pemimpin sekaligus pembimbing. Sejalan dengan pendapat Grinder (dalam Rosiana : 2018) yang mengatakan bahwa peran ayah menjadi penting sebagai figur yang memberikan keputusan anggota keluarga dan mensosialisasikan kepada anaknya yang tumbuh dewasa tentang keunikan gaya hidup berkeluarga.

Altman dan Taylor (dalam Ridwansyah : 2018) mengajukan empat tahap perkembangan hubungan individu-individu yaitu tahap orientasi, pertukaran afektif eskploratif, pertukaran afektif, dan pertukaran stabil. Proses pertukaran informasi yang terjadi selama waktu Ta'aruf ini masuk kedalam tahap orientasi. Dimana pada tahapan ini komunikasi yang terjadi tidak bersifat pribadi atau terlalu mendalam. individu yang terlibat hanya menyampaikan informasi yang bersifat sangat umum saja seperti nama, tempat tanggal lahir, alamat, kekurangan dan kelebihan dan hal - hal umum lainnya yang biasanya sudah banyak orang tau. Informasi yang bersifat umum tersebut kemudian dikemas dalam sebuah CV.

Dari ketiga informan yang melakukan Ta'aruf, hanya 2 informan yang memanfaatkan CV sebagai tahapan awal untuk bertukar informasi. Karena dalam Ta' aruf sendiri tidak ada panduan khusus mengenai media atau tata cara yang harus diikuti, maka informan $\mathrm{G}$ memilih untuk melakukan tahap orientasi dengan langsung berkomunikasi dengan calon pasangannya dengan didampingi oleh mahramnya. Dari semua cara yang dilakukan ketiga informan dapat disimpulkan bahwa proses Ta'aruf boleh untuk dilakukan tanpa atau dengan bertukar CV. Karena tujuan Ta'aruf sendiri adalah untuk berkenalan melalui tata cara yang sesuai dengan syariat islam dan tidak ada pedoman khusus tentang tata cara Ta'aruf dalam Islam melainkan harus sesuai dengan norma antara lawan jenis dan hukum Islam. Maka dari itu, diperbolehkan untuk melakukan komunikasi secara langsung dengan syarat harus didampingi oleh mahramnya.

Jika komunikasi berlanjut untuk saling mengenal lebih jauh, maka mulai masuk kedalam tahapan kedua yaitu pertukaran afektif. Dimana dalam prosesnya terjadi pertukaran informasi yang lebih personal seperi menceritakan pengalaman masa lalu dan individu mulai membuka diri dan saling bertukar opini mengenai diri masing-masing. Proses pertukaran afektif ini dapat dilihat dari aspek keluasan hubungan.

2. Keluasan dan Kedalaman Hubungan

Menurut Jourard (dalam Natalia : 2012) keluasan Self Disclosure dapat terlihat dari enam cakupan kategori informasi yang diberikan yaitu : sikap dan pendapat, perasaan dan minat, pekerjaan atau studi, uang, kepribadian dan tubuh. Informan $\mathrm{F}$ melakukan proses Ta'aruf dengan didampingi oleh ayahnya sebagai perantara. Dilihat dari segi keluasan Self Disclosure yang dilakukan ayah $\mathrm{F}$ sebagai perantara dapat dinyatakan bahwa informasi yang diberikan sudah cukup luas. Ayah F sudah menjelaskan kepada calon pasangan F seputar : Karakter, sifat, pekerjaan, studi, uang, dan kepribadian F.

Menurut Devito (Devito. A. J : 2013) Seorang individu cenderung akan mengungkapkan dirinya berdasarkan seberapa dukungan yang diberikan dan juga akan lebih terbuka kepada orang yang disuka dan dipercaya. Dalam hal ini pengungkapan diri yang dilakukan ketiga informan cukup terbuka dikarenakan calon pasangannya sesuai dengan kriteria yang diinginkan oleh mereka. Alasan individu untuk melakukan pengungkapan diri sangat beragam. Melalui pengungkapkan diri, seorang individu dapat mendorong, mempertahankan, memperbaiki pertumbuhan hubungan.

Keluasan hubungan dalam proses Ta'aruf ini juga dapat dilihat pada saat Nadzar. Dimana dalam tahapan ini kedua belah pihak bertemu untuk melihat satu sama lain dari segi fisik dan juga dapat saling berinteraksi dengan keluarganya masing-masing untuk lebih mengenal satu sama lain. Informan $\mathrm{N}$ menyatakan bahwa pada saat melakukan Nadzar dirinya baru merasa cocok hal ini disebabkan daya tarik fisik juga menjadi faktor kepuasan dalam suatu hubungan. Dayaksini menyatakan adanya hubungan positif antara daya tarik fisik dengan kepuasan hubungan diakibatkan stereotip mengenai seseorang yang memiliki daya tarik fisik yang menarik dapat membuat suatu hubungan menjadi lebih baik dibandingkan 
seseorang yang tidak memiliki daya tarik fisik.

Menurut Miller (dalam Rakhmawati : 2013) Self Disclosure yang dalam adalah ketika seseorang mengungkapkan sesuatu yang bersifat privasi. Kedalaman komunikasi dapat dilihat dari seberapa personal informasi yang diberikan antara kedua belah pihak. Jourard (dalam Sari et al., : 2006) menyatakan dimensi kedalaman pengungkapan diri mengacu pada empat tingkatan pengungkapan diri, yaitu: tidak pernah bercerita kepada orang lain tentang aspek diri, berbicara secara umum, bercerita secara penuh dan sangat mendetail, dan berbohong atau salah mengartikan aspek diri sendiri, sehingga yang diberikan kepada orang lain berupa gambaran diri yang salah.

Tujuan Ta'aruf adalah untuk menikah, sehingga kedua belah pihak pasti memberikan informasi yang cukup rinci dan sedalam mungkin agar tidak terjadi ketidakpuasan hubungan. Karena proses Ta' aruf ketiga informan sendiri berjalan tidak sampai 3 bulan, membuat mereka mengungkapan informasi personal hanya yang berkaitan dengan visi misi pernikahan masingmasing. Menurut Devito (Devito. A. J : 2013) Seorang individu cenderung akan mengungkapkan dirinya berdasarkan seberapa dukungan yang diberikan dan juga akan lebih terbuka kepada orang yang disuka dan dipercaya. Dalam hal ini pengungkapan diri yang dilakukan ketiga informan cukup terbuka melihat calon pasangan mereka sesuai dengan kriteria yang diinginkan. Alasan untuk melakukan pengungkapan diri sangat beragam. Melalui pengungkapkan diri, seorang individu dapat mendorong, mempertahankan, memperbaiki pertumbuhan hubungan.

Kedalam hubungan yang dirasakan ketiga informan mungkin tidak dirasa terlalu intim, karena selama Ta'aruf tidak ada interaksi yang cukup intens antara kedua belah pihak. Komunikasi yang berjalan selalu dengan perantara dan hal ini berpengaruh pada keintiman suatu hubungan. Monsour (dalam Sari et al., ; 2006), Seseorang merasa intim dengan orang lain apabila ia terbantu untuk dapat mengenal, mengetahui dan memahami dirinya sendiri secara lebih mendalam melalui hubungannya dengan orang lain tersebut. Namun, kedalaman suatu hubungan dapat dirasakan dengan adanya aspek kepercayaan antara kedua belah pihak, Kepercayaan merupakan sikap meyakini bahwa tidak ada satu pihak yang mencoba menarik keuntungan dari pihak lain, masing-masing pihak saling menaruh rasa percaya pada satu sama lain (Monsour 1992; Floyd \& Parks, 1996 dalam Sari et al., 2006).

Karena Ta'aruf merupakan hubungan transcendental, dimana tujuan utamanya adalah untuk mendapat ridha Allah swt, maka dari itu ketiga informan selalu menanamkan rasa pasrah dan tawakal selama proses Ta'aruf berlangsung. ketiga informan selalu menanamkan pemikiran selagi sudah berusaha dan berdoa, selebihnya mereka pasrahkan kepada tuhannya. Berpasrah diri menjadi kunci terbentuknya rasa percaya antara kedua belah pihak dan membantu kedalaman hubungan masing-masing. Ketika kedalaman menjadi sangat penting sebagai fondasi sebuah hubungan, perluasan cakupan informasi juga menjadi sama pentingnya. Sangat mungkin suatu hubungan bisa sangat luas tapi tidak mendalam atau sangat dalam tapi tidak terlalu luas.

3. Kepuasan Hubungan

Menurut teori penetrasi sosial, penentuan kepuasan hubungan ditentukan oleh prinsip cost-benefit (analisis untung-rugi). Setelah mengenal seseorang, pada dasarnya kita akan menghitung cost and loss factor atau indeks kepuasan hubungan dalam hubungan dengan orang tersebut. Jika hubungan nya dirasa saling menguntungkan, kemungkinan besar akan terus berlanjut, dan proses penetrasi sosial juga terus berlanjut. Analisis untung rugi ini dapat dilihat langsung setelah pertemuan pertama atau jika dalam tahapan penetrasi sosial disebut dengan tahap orientasi.

Tahapan orientasi dalam proses Ta'aruf terjalin pada saat pertukaran informasi sesaat sebelum proses Nadzar terjadi. Pada masa orientasi tersebut ketiga informan sudah merasa cukup puas dengan informasi yang didapat, hal ini dapat disimpulkan karena adanya kelanjutan hubungan yang mereka lakukan yaitu ke tahap Nadzar. Menurut Hendrick \& Adler (dalam Iskandar : 2017), kepuasan dalam hubungan berawal dari komunikasi yang terjalin dengan baik. Melalui komunikasi, individu dapat mengenal pasangannya lebih baik dan kurangnya komunikasi dapat menyebabkan ketidakpuasan dan akan menjadi penyebab 
terjadinya pemutusan suatu hubungan.

Kepuasaan adalah perasaan yang dimiliki individu ketikan keinginannya terpenuhi. Dalam hal ini ketiga informan menyatakan bahwa keinginan mereka untuk memiliki calon suami idaman sudah terpenuhi, melihat bahwa kriteria suami yang dimiliki masing-masing informan secara garis besar sudah dimiliki oleh pasangan Ta'aruf nya. Maka dari itu dapat disimpulkan bahwa adanya kepuasan yang dirasakan ketiga informan atas calon pasangan yang dimilikinya. Ketiga informan secara garis besar menyatakan bahwa saat memilih calon pasangan, yang menjadi kebutuhan mereka adalah untuk memiliki calon pasangan yang bisa mengerti, menyayangi dengan tulus dan bertanggung jawab. Dimana kebutuhan tersebut merupakan kebutuhan emosional yang dibutuhkan untuk membentuk rasa nyaman dan percaya akan pilihan yang mereka pilih. Dan dari kebutuhan-kebutuhan emosional yang diungkapkan oleh ketiga informan, mereka merasakan kepuasan saat mengetahui jika calon pasangannya dapat memenuhi kebutuhan tersebut.

\section{Keseluruhan Hasil Penelitian}

Tabel 4. Hasil Penelitian

\begin{tabular}{|c|c|c|c|}
\hline \multicolumn{4}{|c|}{ Pengalaman Self Disclosure } \\
\hline \multicolumn{4}{|c|}{ Komunikasi Interpersonal Dilihat Melalui Penetrasi Sosial } \\
\hline \multicolumn{2}{|c|}{ Tahapan Ta'aruf } & \multicolumn{2}{|c|}{ Aspek Self Disclosure } \\
\hline Orientasi & $\begin{array}{l}\text { Bertukar CV dan } \\
\text { Proses } \\
\text { observasi } \\
\text { sebelum } \\
\text { memutuskan } \\
\text { untuk nadzar }\end{array}$ & $\begin{array}{l}\text { Pertukaran } \\
\text { Informasi }\end{array}$ & $\begin{array}{l}\text { Selama menjalani ta'aruf, komunikasi berlangsung melalui perantara } \\
\text { dan informasi yang diberikan hanya berdasarkan } \mathrm{CV} \text { dan opini } \\
\text { atau cerita dari keluarga atau teman dekat kedua belah pihak. }\end{array}$ \\
\hline Afektif & $\begin{array}{l}\text { Nadzar dan proses } \\
\text { saling mencari } \\
\text { informasi } \\
\text { melalui } \\
\text { perantara } \\
\text { masing- } \\
\text { maisng. }\end{array}$ & $\begin{array}{l}\text { Kedalaman dan } \\
\text { Keluasan } \\
\text { Hubungan }\end{array}$ & $\begin{array}{l}\text { Kedalaman dan keluasan informasi yang diberikan hanya sebatas } \\
\text { perbincangan mencakup kehidupan setelah pernikahan, selebihnya } \\
\text { mengenai aspek pribadi satu sama lain dirasa tidak terlalu penting } \\
\text { selagi masih ada beberapa sifat-sifat umum yang telah diketahui } \\
\text { oleh satu sama lain. }\end{array}$ \\
\hline Eksploratif & - & $\begin{array}{l}\text { Kepuasan } \\
\text { Hubungan }\end{array}$ & $\begin{array}{l}\text { Calon pasangan yang mereka dapat sesuai dengan kriteria yang } \\
\text { diinginkan, dapat memenuhi kebutuhan dan keinginan emosional } \\
\text { mereka dan melalui ta'aruf bisa menjaga kehormatan serta } \\
\text { kesucian diri wanita. }\end{array}$ \\
\hline
\end{tabular}

\section{Kesimpulan}

Berdasarkan pembahasan dalam penelitian ini, peneliti menyimpulkan beberapa hasil penelitian sebagai berikut:

1. Pengalaman Self Disclosure ketiga wanita dilihat dari kacamata penetrasi sosial terbagi kedalam empat proses yaitu : pertukaran informasi, kedalaman dan keluasan hubungan, serta kepuasan hubungan. Selama berjalannya Ta'aruf ketiga wanita tidak melakukan komunikasi yang bersifat intim dengan calon pasangannya, informasi yang diberikan hanya berdasarkan CV dan opini atau cerita dari keluarga atau teman dekat kedua belah pihak. Kedalaman dan keluasan informasi yang diberikan hanya sebatas perbincangan mencakup kehidupan setelah pernikahan, selebihnya mengenai aspek pribadi satu sama lain dirasa tidak terlalu penting selagi masih ada beberapa sifat-sifat umum yang telah diketahui oleh satu sama lain. Secara keseluruhan ketiga wanita merasa puas akan hubungan yang telah mereka jalani melalui Ta'aruf karena calon pasangan yang mereka dapat sesuai dengan kriteria yang diinginkan, dapat memenuhi kebutuhan dan keinginan emosional mereka dan melalui Ta'aruf bisa menjaga kehormatan serta kesucian diri wanita. 


\section{Daftar Pustaka}

[1] Pengadilan Tinggi Agama (PTA) Jabar, "Statistik Perkara Pengadilan Agama Se-Jawa Barat." Si Kabayan, http://kabayan.pta-bandung.go.id/pengawasan_sipp/\#

[2] B. Adler, R., \& Rodman, G. 2006. "Understanding Human Communication". Oxford University Press.

[3] Borualogo, I. S., \& Rahmatinna. 2011 "Studi Mengenai Kepuasan Pernikahan Pada Pasangan Suami Istri Yang Menikah Melalui Ta'aruf Di Bandung" dalam Schema: Journal of Psychological Research. Volume 2, Nomor 1 (hlm 20-30)

[4] Defrian, A. 2015. "Pengungkapan Diri Ditinjaudari Harga Diri Dan Jenis Kelamin Pada Mahasiswa Psikologi Uin Suska Riau". Skripsi. Riau: Universitas Islam Negeri Sultan Syarif Kasim.

[5] Devito. A. J. 2013. “The Interpersonal Communication Book (13th Edition)”. Pearson

[6] Hamdan, Juwaeni. 2009. "Studi Tingkat Self-Disclosure Siswa-Siswi Sekolah Umum dan Santri/wati Pondok Pesantren" Skripsi. Malang: Universitas Islam Maulana Malik Ibrahim.

[7] Iskandar, L. 2017. "Hubungan Antara Kepuasan Hubungan Romantis Dengan Intensi Berselingkuh Pada Mahasiswa" Skripsi. Universitas Sanata Dharma

[8] Kadarsih, R. 2009. "Teori Penetrasi Sosial Dan Hubungan Interpersonal" dalam Jurnal Dakwah. Volume 10, Nomor 1 (hlm 53-66)

[9] Khairani, R., \& Putri, D. 2008. "Kematangan Emosi Pada Pria Dan Wanita Yang Menikah Muda". Jurnal Ilmiah Psikologi Gunadarma. https://doi.org/10.35760/psi

[10] Natalia, T. christine. 2012. "Hubungan Antara Harga Diri Dengan Pengungkapan Diri Pada Mahasiswi". Skripsi. Semarang: Universitas Katolik Soegijapranata

[11] Nawangsih, E., Rosiana, D., \& Sarjono, A. D. 2010. "Model Intervensi untuk Meningkatkan Penyesuaian Pernikahan bagi Pasangan yang melalui Proses Ta'aruf ". Prosiding SNaPP2010

[12] Prambudi, A. 2016. "Proses Penetrasi Sosial Antara Pekerja Sosial Dengan Wanita Rawan Sosial Psikologis (Studi Kasus Di Balai Perlindungan Dan Rehabilitasi Sosial Wanita Yogyakarta )". Skripsi. Yogyakarta: Universitas Muhamadiyah

[13] Rakhmawati, F. 2013. "Self disclosuredalam Ta'aruf Pranikah Kader Partai Keadilan Sejahtera (PKS)" dalam Interaksi: Jurnal Ilmu Komunikasi. Volume 2, Nomor 1 (hlm 11-21)

[14] Ridwansyah, R. 2018. "Proses Komunikasi Interpersonal dalam Ta'aruf di Kota Banda Aceh" dalam Jurnal Komunikasi Global

[15] Rorong, M. J. 2018. "Realitas Dalam Hubungan Manusia Melihat Dalam Perspektif Teori Serta Kedekatan Komunikasi Antar Individu". Dalam Jurnal Oratio Directa. Volume 1, Nomor 1, (hlm 34-43)

[16] Rosiana, T. 2018. "Peran Ayah Dalam Pemilihan Pasangan Hidup Anak Remaja" Skripsi. Jakarta : Universitas Negeri Jakarta

[17] Santika, I. G. P. N. A. 2015. "Hubungan Indeks Massa Tubuh (Imt) Dan Umur Terhadap Daya Tahan Umum (Kardiovaskuler) Mahasiswa Putra Semester Ii Kelas A Fakultas Pendidikan Olahraga Dan Kesehatan Ikip Pgri Bali Tahun 2014”. Dalam Jurnal Pendidikan Kesehatan Rekreasi. Volume 1, (hlm 42-47)

[18] Sari, F., \& Sunarti, E. 2013. "Kesiapan Menikah pada Dewasa Muda dan Pengaruhnya terhadap Usia Menikah". Dalam Jurnal Ilmu Keluarga Dan Konsumen. Volume 6, Nomor 3, (hlm 143 